\title{
Suitability Analysis For Scuba Diving To Develop Marine Tourism At Saebus Island, East Java, Indonesia
}

\author{
Putranto Wijaya ${ }^{1,2, *}$, Tri Putra $^{1,2}$, Fatra Hidayat $^{1,3}$, Chandra Levraeni ${ }^{1,2}$, Mada Rizmaadi $^{1,2}$, and Ambariyanto \\ Ambariyanto ${ }^{2,3}$ \\ ${ }^{1}$ UKSA-387 Diving Club Diponegoro University, 50275 Jl. Prof. Soedarto SH, Tembalang Campus, Semarang, Indonesia \\ ${ }^{2}$ Faculty of Fisheries and Marine Science, Diponegoro University, 50275 Jl. Prof. Soedarto SH, Tembalang Campus, Semarang, \\ Indonesia \\ ${ }^{3}$ Coastal Disaster Rehabilitation and Mitigation Center, Integrated Laboratory, Diponegoro University, 50275 Jl. Prof. H. Soedarto, SH, \\ Tembalang, Semarang, Indonesia
}

\begin{abstract}
Indonesian government currently has policies to improve the performance of the tourism sector, including marine tourism. One of the attractions of marine tourism is the coral ecosystem especially through scuba diving activities. The purpose of this study was to determine the suitability of the coral ecosystem on Saebus Island, East Java, to find appropriate locations for scuba diving activities. Purposive samplings were done around the island to determine four stations which will be assessed through suitability analysis. Tourism Suitability Index was used to assess all stations for scuba diving activities. The result showed that all four stations were categorized as very suitable with the score: $85 \%$, $85 \%, 85 \%$ and $83 \%$, respectively. Several aspects that need to be improved and anticipated for diving at all stations are coral coverage and water current. These results suggest that there are several spots around Saebus Island that are suitable for diving site, and can be promoted as marine tourism destination.
\end{abstract}

\section{Introduction}

Coral reef ecosystem is known to have important role and high biological diversity. However, this ecosystem is also one of the most vulnerable marine ecosystems damaged by human activities. Several anthropogenic activities can caused marine organisms become endangered including those live in coral reef ecosystem [1].

Conservation action is one of the ways to prevent damage on coral reef condition. Non extractive activities such as properly manage marine tourism can also reduce the impact of damage caused by human exploitationon coral reefs [2]. At the same time, it provides solutions for conservation activities in the area. Therefore, with its high biological diversity and its uniqueness, coral reef ecosystem can be used as a marine tourism $[3,4,5]$.

Saebus Island is known to have pristine coral reefs around the island. It is located in District Sapeken, East Java, which has 126 islands with an area of 2093.45 $\mathrm{km}^{2}$. The utilization of marine resources by the community in the area is mainly on capture fisheries [6]. High pressure on marine resources through fishing activities will have an impact on the sustainability of marine resources [7]. Destructive fishing methods such as using bombs and cyanide poison at coral reef ecosystem are still common in the area [2]. These activities will damage the ecosystems and losing its diversity. Whilst as for other activities such as marine aquaculture and marine tourism is still not maximally utilized.

Coastal Saebus Island has a stretch of white sand beaches and clear waters. In addition, diversity and abundance of marine organisms are also high [6]. Clear waters and natural beauty under the sea with an abundance of coral reefs and very divers marine organisms on the island of Saebus is potential to be developed into a dive site. However, there is no scientific study on the possibility of developing marine tourism in the area. Several reports show suitability for marine tourism $[8,9]$. This study determines the suitability of Saebus Island coral reef ecosystem for diving activities by looking at biological and no biological parameters, as part of the development of marine tourism.

\section{Methods}

This research was conducted in November 2016 at Saebus Island, Sapeken, East Java. Determination of four survey locations was done by purposive sampling method [10]. Considerations taken was the existence of coral ecosystems by using Aster satellite image results. See Figure 1. 


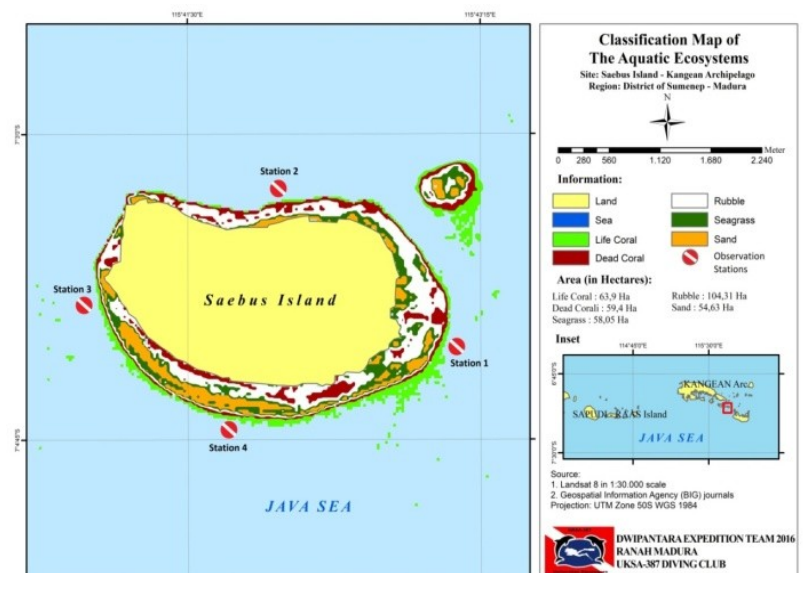

Figure 1. Map of research location

\subsection{Field observation}

\subsubsection{Coral coverage and species}

Coral coverage was measured with Line Intercept Transect (LIT) method by using 100 meters roll meter with precision in centimetre $(\mathrm{cm})$. Percentage of coral cover was measured based on English et al. formula [11]. Coral reef measurement procedure begins with the installation of a 50-meter-wide line transect or line without intervals with the accuracy of the line transect scale in centimetres $(\mathrm{cm})$ [12].

\subsubsection{Fish species}

Coral fish observation was done by using visual census method as the line with coral coverage observation. The measurement of reef fish data was done by recording the number of species of reef fish up to 2.5 meters to the left and 2.5 meters to the right of the transect line [13]. Then identify the fish using illustrated instruction manuals [14].

\subsubsection{Water parameters}

Water transparency was measured by using secchi disk and calculated by Effendi's formula [15]. Water current was measured using a floating ball with rope [16]. The depth of the water was measured by utilizing the depth gauge, part of diving console regulator tools [17]. Depth measurements were made when it reaches the bottom the waters.

\subsection{Data analysis and suitability analysis}

\subsubsection{Scoring and assessment}

Scoring and assessment were done by using all parameter data. Scoring was based on the value of the parameter, while for the assessment was given on each parameter with weight value of 5,3, and 1 showing the effect of parameters towards suitability of diving tourism. The greater the influence of these parameters the greater the assessment given. The description given for the parameter is Very Appropriate (S1), Quiet Appropriate (S2), Appropriate Conditionally (S3) and not Appropriate $(\mathrm{N})$. Scoring and assessment of the dive tourist suitability index are outlined in Table 2 .

\subsubsection{Suitability tourism index analysis}

The index can be measured from the parameter value divided by max value of from tourism category [18].The value of Suitability Tourism Index (IKW) were divided into four suitability classes (see Table 1).

Table 1. Suitability matrix for diving tourism [18]

\begin{tabular}{|l|c|c|c|c|c|c|c|c|c|}
\hline \multirow{2}{*}{ Parameter } & & Category & & Category & & Category & & Category & \\
\cline { 2 - 11 } & Value & S1 & Score & S2 & Score & S3 & Score & N & Score \\
\hline Visibility (\%) & 5 & $>80$ & 3 & $50-80$ & 2 & $20-<50$ & 1 & $<20$ & 0 \\
\hline Coral coverage (\%) & 5 & $>75$ & 3 & $>50-75$ & 2 & $25-50$ & 1 & $<25$ & 0 \\
\hline Fish species (n) & 3 & $>100$ & 3 & $50-100$ & 2 & $20-<50$ & 1 & $<20$ & 0 \\
\hline Coral lifeform (n) & 3 & $>12$ & 3 & $>7-12$ & 2 & $4-7$ & 1 & $<4$ & 0 \\
\hline Water current (cm/s) & 1 & $0-15$ & 3 & $>15-30$ & 2 & $>30-50$ & 1 & $>50$ & 0 \\
\hline Coral depth (m) & 1 & $6-15$ & 3 & $3-<6$ & 2 & $>20-30$ & 1 & $<3$ & 0 \\
\hline
\end{tabular}

Table 2. Suitability diving tourism categories [18]

\begin{tabular}{|l|c|}
\hline \multicolumn{1}{|c|}{ Category } & Index Value \\
\hline Very Appropriate (S1) & $>83-100 \%$ \\
\hline Quite Appropriate (S2) & $>50-83 \%$ \\
\hline Appropriate Conditional (S3) & $>17-50 \%$ \\
\hline Not Appropriate (N) & $17 \%$ \\
\hline
\end{tabular}




\section{Results}

\subsection{Field observation}

Suitability study for scuba diving sites, consist of several parameters. Parameters that measured in field observations were percentage of coral cover, coral diversity, diversity of fish species, visibility, current velocity, coral reef depth and coral reef condition. The result of parameters measurement obtained from field observation is presented in table below:

Table 3. Result of parameters measurement on Saebus Island waters

\begin{tabular}{|l|c|c|c|c|}
\hline \multirow{2}{*}{\multicolumn{1}{|c|}{ Parameters }} & \multicolumn{4}{c|}{ Stations } \\
\cline { 2 - 5 } & $\mathbf{1}$ & $\mathbf{2}$ & $\mathbf{3}$ & $\mathbf{4}$ \\
\hline Visibility (m) & 10 & 10 & 10 & 10 \\
\hline Coral coverage (\%) & 68 & 63 & 58 & 60 \\
\hline Fish species (n) & 36 & 32 & 30 & 49 \\
\hline $\begin{array}{l}\text { Coral } \\
\text { lifeform/genus(n) }\end{array}$ & 13 & 17 & 16 & 15 \\
\hline Sea current (cm/s) & 0,05 & 0,05 & 0,06 & 0,17 \\
\hline Coral depth (m) & 10 & 10 & 10 & 10 \\
\hline
\end{tabular}

Generally, the condition of Saebus Island waters still looks natural. Based on the results, the condition of the waters of Saebus Island has good clarity with visibility reaches up to \pm 10 meters in each station, and belong to S1 category. Very good for scuba diving activities that will make the diver comfortable. Current speed at station 1 - station 3 is classified S1 with speed $0.05-0.06 \mathrm{~cm} / \mathrm{s}$. While at station 4 pertained S2 because current velocity $0,17 \mathrm{~cm} / \mathrm{s}$. Coral cover is quite good with the range $58-63 \%$ included in the category S2. The coral genus was found on average 15 genera of corals in each station classified as S1 category. The diversity of fish in the study sites was classified into S3 category in each station with the findings of 30-49 fish species in each station. The station that has the highest diversity of fish is the 4 th station. The depth of coral at saebus island is very suitable (S1) for scuba diving activity with depth up to \pm 10 meters.

\subsection{Suitability analys is}

Suitability analysis for scuba diving tourism sites was analyzed based on parameter measurement results (Table 3) [18]. The results of the assessment of the suitability of scuba diving sites are presented in the table 4 .

The suitability of the location obtained for diving in Saebus Island waters shows that for the four stations observed included in the category of 'Very Appropriate' (S1) with the value of $85 \%, 85 \%, 85 \%$, and $83 \%$. These value meets the S1 category because it is within the value range $>83-100 \%$ [18].
Table 4. Dive tourism index value

\begin{tabular}{|l|c|c|c|c|}
\hline \multirow{2}{*}{ Parameters } & \multicolumn{4}{c|}{ Stations } \\
\cline { 2 - 5 } & $\mathbf{1}$ & $\mathbf{2}$ & $\mathbf{3}$ & $\mathbf{4}$ \\
\hline Visibility (\%) & 15 & 15 & 15 & 15 \\
\hline Coral coverage (\%) & 10 & 10 & 10 & 10 \\
\hline Fish species (n) & 2 & 2 & 2 & 2 \\
\hline Coral lifeform/genus (n) & 9 & 9 & 9 & 9 \\
\hline Sea current (cm/s) & 3 & 3 & 3 & 2 \\
\hline Coral depth (m) & 3 & 3 & 3 & 3 \\
\hline Total & 49 & 49 & 49 & 48 \\
\hline $\begin{array}{l}\text { Suitability Tourism Index } \\
\text { (\%) }\end{array}$ & 85 & 85 & 85 & 83 \\
\hline Category & $\mathrm{S} 1$ & $\mathrm{~S} 1$ & $\mathrm{~S} 1$ & $\mathrm{~S} 1$ \\
\hline
\end{tabular}

\section{Discussions}

\subsection{Waters current}

Sea currents in Saebus Island ranged from $0.05-0.17$ $\mathrm{m} / \mathrm{s}$. This current condition affects the level of safety and comfort in tourism activities. Based on these results, it is included to very appropriate category. The current belonging to a suitable state for diving activity ranges from $0-15 \mathrm{~cm} / \mathrm{s}[19]$. Flow is a limiting factor in the suitability of dive tourism that affects the movement of divers to regulate its balance. According to [18], the current with relatively weak flow velocity is ideal for diving tourism.

\subsection{Visibility}

Transparency is one parameter for diving activity which affects the visibility of the water. The result shows that all stations have water visibility value of 10 and can be categorized as good aspect. The category for visibility that suitable for diving area is good if the value between $80-100 \%$ [18]. Therefore, all stations were scored 3 on the four stations. The high scores can be affected by shallow water depths that have been penetrated by sunlight into the water column.

\subsection{Coral Reefs Areas}

Based on the field observation, it was found that coral cover value from the four stations ranged from $58 \%$ $68 \%$ so it was rated 2 for each observation station. The scores are categorized in appropriate [18] said, that coral coverage between $50-70 \%$ categorized as appropriate for diving activity. The species that dominate on Saebus island are Acroporasp.,Porites sp. and Pocillopora sp.The depth of coral reefs in Saebus Island were categorized into shallow waters with the fringing reefs characteristic. Generally, this type is located in the edge of the island [21].The results showed that the depth of coral reefs at all four stations were classified into two grades. Stations 1 and 3 have a score of 0 that fall into the inappropriate category, while stations 2 and 4 scored 3 which can be classified as very suitable. A very suitable depth for diving is 
located on stations 2 and 4 with depths of 9 and 10 meters. The depth of coral reefs suitable for diving activities ranged from 6 to $15 \mathrm{~m}$ [18]. Diving at a location with a strong current is not recommended but, if forced to dive then the divers involved must be experienced [22].

\subsection{Coral fish}

The number of species of reef fish found in the waters of Saebus Island is categorized as Quite Appropriate (S2). This is because the number of species of fish found more than 20 species. The types of reef fish found in each research station were Pomacentridae and Abudefduf. Report shows that Pomacentridae fish is very common in coral reefs [23]. Four Chaetodon fishes were found at station 3. These fish are indicator of coral reef health. This is in accordance with the value of coral cover at station 3 i.e. $60 \%$ which is included in the good category [18]. Fish from Chaetodontidae family are coral health indicator fish with habit of eating coral polyp as food source [23].

\subsection{Determination for tourism suitability}

Parameters measured in field observations are taken into consideration to assess how appropriate the location to scuba diving sites refers to conformity assessment [18]. The results show that the waters of all stations at Saebus Island can be included in the suitability class S1 (Very Appropriate) with the Suitability Diving Tourism Index at $85 \%, 85 \%, 85 \%$, and $83 \%$, respectively.

Determination of these values can not be separated from the relationship between the parameters of the suitability of diving tourism. Some reports show that coral coverage affects the number and biodiversity of coral fish $[24,25]$. It is evident that each station has an appropriate coral cover level proportional to the number of reef fish available. Although each parameter affects each other in the suitability of the dive tour, not every parameter will be well correlated. Stations 1, 2, and 3 have a rating of the suitability of diving tourism index of $91 \%$ and classified as very appropriate (S1), but these locations have coral cover score categorized as appropriate (S2). This value indicates that the coral cover in the area is quite good. As for station 4, has a value of $89 \%$. The conformity index value at station 4 is lack of coral cover parameters and current velocity. Each value belongs to a category quite appropriate (S2). It should be noted that for diving activities with existing current conditions there is a need of assistance in order to improve safety diving [26].

\section{Conclusions}

Saebus Island waters is suitable for scuba diving area and can be develop for marine tourism. The value of suitability index for diving tourism in every station are $85 \%, 85 \%, 85 \%$, and $83 \%$. So categorized in very Appropriate Category (S1).

\section{Acknowledgements}

This research was held by UKSA-387 Diving Club Diponegoro University on Dwipantara V Expedition: Kangean Archipelago "Jelajah Pesona Bahari Tampuk Timur Madura". We thanks to UKSA-387 Diving Club families who have fully supported and big appreciation to the Dwipantara V Expedition Team who has worked hard in this project. This project depends on logistical and field support from a number of contributed peoples. We thanks to the Department of Fisheries and Marine East Java Province, Indonesia. Mr. $\mathrm{H}$. Muhammad Ali, Mr. Osnan, Saur-Saebus village and Sapeken Sub-district governments, as well as the entire community of Saebus and Sapeken Islands for supports this research.

\section{References}

1. Ambariyanto. In IOP Conference Series: Earth and Environmental Science. 55,1: 012002. doi: doi:10.1088/1755-1315/55/1/012002 (2017).

2. B. Tamam, A. Apri, and Saleh. J. Kelautan, 6,2: 120-127. DOI: http://dx.doi.org/10.21107/ jk.v6i2.785 (2013).

3. N. Riyan, Thesis. Fakultas Perikanan dan Ilmu Kelautan Institut Pertanian Bogor (2007).

4. H. Apriyanto, A. Wahyu and Umroh. Akuatik, 10,2: $30-38$ (2016)

5. M.H. Natha, A. Tuwo, and F. Samawi, J. Sains \& Teknologi, 14,3: 259 - 268 (2014).

6. Sutanto, M.A., Bedjo, R., and Elisabeth, C.Y. Petra University, Surabaya, (2013)

7. V. Siwat, A. Ambariyanto, I. Widowati, AACL Bioflux, 9,4:915-922 (2016).

8. P. Subardjo, and N.I. Hidayat, Ilmu Kelautan: Indonesian Journal of Marine Sciences, 12,4:211218. DOI: https://doi.org/10.14710/ ik.ijms.12.4.211-218. (2007)

9. A. Fahrudin, and Y. Wardiatno, Research Report. Intitut Pertanian Bogor, Bogor. (2010)

10. Sugiyono. Alfabeta, Bandung, 330 p (2011)

11. English, S., Wilkinson, C., and Baker, V. Australian Institute of Marine Science, Townsville, $368 \mathrm{p}$ (1994)

12. S. Adibrata, Jurnal Kelautan, 6,1: 19-28. DOI: http://dx.doi.org/10.21107/jk.v6i1.829 (2013)

13. Dedi. Thesis. Departemen Pengelolaan Sumber Daya Perairan, Universitas Bangka Belitung, Bangka (2012).

14. G.R. Allen, Periplus Perth, Australia, (1997)

15. H. Effendi, Living Aquatic Resources Management, 292. DOI:http://repository.ipb.ac. $\mathrm{id} /$ handle/123456789/79927 (2003)

16. H. Huttagalung, and A. Rozak. Puslitbang Oseanologi-LIPI, Jakarta, 35 pp. (1997)

17. B.A. Adi, A. Mustafa, and R. Ketjulan. Jurnal Mina Laut Indonesia, 01,01: 1-13 (2013)

18. F. Yulianda, Makalah Seminar Sains, 21 (2007). 
19. Supriharyono. Pustaka Pelajar, Yogyakarta, $428 \mathrm{p}$ (2007).

20. L.S.H. Yulius, Ramdhan, M., Arifin, T., and Purbani, T. Globe, 15,2 : 129-136. DOI: http://dx.doi.org/10.24895/MIG.2013.15-2.\%25 x (2013).

21. Suharsono. LIPI, Jakarta, 372 pp. (2008)

22. M. Philips, University of Queensland, Australia, 126 p. 2006

23. F. Kurniawan, R.F.D. Destilawaty, S.G.A. Dedi, and Tabunan, J.M. Prosiding Seminar Nasional Perikanan dan Ilmu Kelautan,V:432-442 (2015).
24. J.D. Bell, and R. Galzin, Marine Ecology Progress Series, 15,3: 265-274 (1984).

25. G.P. Jones, M.I. McCormick, Srinivasan, M. and J.V. Eagle, Proceedings of the National Academy of Sciences of the United States of America, 101,21: 8251-8253 (2004).

26. Abidin, S.Z., and Mohamed, B. A.SHS Web of Conferences, 12, 01093. DOI: 10.1051/ shsconf/20141201093 (2014). 